\title{
Strengthening the university competitiveness in the Czech Republic
}

\author{
Helena Chládková, Renata Skýpalová, and Veronika Blašková*
}

doi: http://dx.doi.org/10.18543/tjhe-9(1)-2021pp127-155

Received: 16 April 2021

Accepted: 23 October 2021

\begin{abstract}
The number of students at Czech universities had been growing continuously until 2010. In 2010, almost 400,000 students studied there. Since then, this number has declined every year. Pressure on present-day universities has been accruing due to the competitive environment. The only way to strengthen competitiveness is to improve constantly the quality and image. The objective of this paper is to verify what factors are important for students regarding their satisfaction and what factors could be key for supporting the competitiveness of the Czech universities. To assess student satisfaction, the authors conducted a questionnaire survey where students were asked to identify the strengths and weaknesses of the faculty. The survey was carried out within the Faculty of Business and Economics of Mendel University in Brno (FBE MENDELU) and a selected private university in Brno in 2019. Relative frequencies were used in data processing and statistical hypotheses were tested. In addition to the basic classification according to one feature, a combination classification was also processed, and the independence was tested for different combinations of questions. Of the total number $(1,020)$ of identified strengths at FBE MENDELU, 57.7\% of students stated, "quality teachers", $32.4 \%$ "faculty image" and 31.8\% "modern environment" as strengths. Regarding the identified weaknesses, the most frequently mentioned were "study difficulty (42.4\%)," weaker image of the university with the public " $(31.5 \%)$ and not enough practical training (23.2\%). At the private college, $47.8 \%$ of respondents cited "quality teachers", "interesting lectures and teaching methods" (40.8\%) and "study materials for subjects" (29.4\%) as the school's strengths.
\end{abstract}

* Helena Chládková (corresponding author, chlad@mendelu.cz) is Associate Professor in Economics and Management at Mendel University in Brno in the Czech Republic.

Renata Skýpalová (renata.skypalova@ambis.cz), PhD in Economics and Management, is an assistant professor at Ambis College, a.s. in Brno in the Czech Republic.

Veronika Blašková (veronika.blaskova@mendelu.cz) is Associate Professor in Economics and Management at Mendel University in Brno in the Czech Republic.

More information about the authors is available at the end of this article. 
Keywords: Czech universities; university students; university rankings; questionnaire survey; strengths; weaknesses; quality; competitiveness.

\section{Introduction}

In today's globalized economy, universities play a key role and create a significant contribution to the economic and knowledge development of the population. They produce a lot of qualified and educated people who put their acquired knowledge into practice within a complex socio-economic structure. ${ }^{1}$ Higher education is a global game. Its success or failure represent an integral part and the important indicator of the ability of individual states to produce knowledge and attract talent. ${ }^{2}$ Universities have been gradually adopting new organizational structures and forms to acquire the ability to adapt and meet the needs of the outside world. In addition, in the last two years, higher education, like many other disciplines, has affected the Covid pandemic, in particular the need to switch to online teaching. Therefore, they operate in a market-business environment with the emphasis on innovation. ${ }^{3}$ Increased volatility in the external environment brings the need to adopt forms of strategic management that meet current requirements to increase the effectiveness of higher education organizations. Strategic management as said Clark can be defined using the techniques, tools, methods, models, frameworks, and approaches available to support strategic management decision-making. According to Clark, strategic corporate governance can be defined using techniques, tools, methods, models, frameworks and approaches available to support decision-making in the field of strategic management. ${ }^{4}$ Strategic planning and benchmarking reflect the different perspectives of universities and provide guidance and recommendations to facilitate the promotion of universities in a globalized economy. Strategic planning is a

${ }^{1}$ Indicators of the Strategy of Educational Policy of the Czech Republic until 2020, [Indikátory strategie vzdělávací politiky České republiky do roku 2020] Ministry of Education, Youth and Sports (MEYS) online, January 12, 2014, https://www .msmt.cz/file/34419/.

${ }^{2}$ Ellen Hazelkorn, "Rankings and Higher Education: Reframing Relationships within and between States," Center for global higher education, May 2017, https://www .researchcghe.org/ publications/working-paper/rankings-and-higher-education-reframing-relationships-withinand-between-states/.

${ }^{3}$ Sara Javan Amoli and Farnouche Aghashahib, "An Investigation on Strategic Management Success Factors in an Educational Complex," Procedia - Social and Behavioral Sciences 230 (September 12, 2016): pp. 447-454, https://doi.org/10.1016/j.sbspro.2016.09.056.

${ }^{4}$ Delwyn N. Clark, "Strategic Management Tool Usage: A Comparative Study," Strategic Change 6, no. 7 (November 1997): pp. 417-427, https://doi.org/10.1002/(SICI)10991697(199711)6:7<417: AID-JSC281>3.0.CO;2-9. 
way of thinking that is gaining considerable attention from many universities in different countries. ${ }^{5}$ According to the Ministry of Education, Youth and Sports, there are 26 public universities, 2 state universities and 33 private universities in the Czech Republic in 2020. In addition, 18 foreign universities or their branches also provide higher education. ${ }^{6}$ To increase competitiveness, it is necessary for them to improve constantly, look for gaps in the market and use their strengths. According to the annual reports and strategic plans of Czech universities, for most of them the implementation of the strategic plan means the introduction of a system of internal evaluation and quality assurance, which will lead to an increase in the quality of all activities and the acquisition of institutional accreditation. They also want to improve the placement of their faculties and implemented fields in renowned international rankings. In connection with the topic of the quality of education and competitiveness of higher education institutions, the analysis of the external environment shows that the directly influencing, negative effect of the external environment is mainly the persistent seclusion of Czech higher education and an unwillingness to cooperate among various entities (public - private universities). Another important factor influencing the decision making of potential students is the reputation of universities, which seems to be worse for private schools from the public's point of view rather than for public schools. $^{7}$

\section{Theoretical background}

According to Ondrušová total 290,000 students studied in the Czech Republic the vast majority (90.2\%) at public universities in 2018. The number of students at Czech universities had been growing until 2010, when almost 400,000 studied at them, and since then the number has declined every year. The fall in the number of students is mostly related to bachelor's degree programs. 8 This decrease causes both, a reduction in the demographic

5 Zenia Barnard and Derek Van der Merwe, "Innovative Management for Organizational Sustainability in Higher Education," International Journal of Sustainability in Higher Education 17, no. 2 (March 7, 2016): pp. 208-227, https://doi.org/10.1108/ IJSHE-08-2014-0120.

${ }^{6}$ Overview of Universities in the Czech Republic, [Přehled vysokých škol v ČR] Ministry of Education, Youth and Sports (MEYS), accessed July 2020, https://www.msmt.cz/vzdelavani/ vysoke-skolstvi/prehled-vysokych-skol-v-cr-3.

7 Julie Šmejkalová, "The Process of Evaluating Strategic Trends in the Provision of Quality Higher Education-Analysis of the External Environment," Economic Letters (College of Economics and Management, December 28, 2016), http://search.ebscohost.com/login.aspx? direct $=$ true $\& d b=b s u \& a n=120576379 \&$ scope $=$ site. 
curve, and market saturation in the case of applicants who needed to supplement their education in connection with a change in qualification requirements for certain professions (e.g., nurses, police officers) ${ }^{8}$ According to the authors, the most significant factor influencing the decline in the number of students at universities is the declining size of the population aged 20 to 29 , i.e. the age typical for university studies. Other important factors include changes in the organization of higher education, the current needs of society and, last but not least, the way in which higher education is financed. Universities do not fill their capacities - but this does not apply to all fields; an excess of demand and lower chance of acceptance mainly relates to humanities, social sciences, and medical disciplines. Due to the large number of applicants, these faculties can still choose the best students. Therefore, these universities also require entrance exams. Traditionally, the most difficult entrance exams in the Czech Republic are exams in the fields of art, because they require talent exams. Furthermore, the admission procedure to study medicine, law, psychology, journalism and international relations is difficult. The form of the entrance examinations may vary according to the type of university, tests of study prerequisites may be used or Scio, which organizes national comparative examinations, may be used. Some universities do not take entrance exams at all and accept students according to their high school results. Of course, private universities do not require entrance exams. On the contrary, regarding less interest being shown in technical fields, technically oriented faculties accept the most applicants..$^{9}$ Every sixth university student is a foreigner (representing $15.5 \%$ of students). A total of 44.8 thousand of them are studying at public and private universities in the Czech Republic in 2020. Ten years ago, only every 12th student at public and private universities was a foreigner. If we focus only on private universities, foreigners represent almost a fifth of all students (19.6\%). Foreigners make up $14.5 \%$ of public universities. ${ }^{10}$ Despite the increase in the percentage of university students, Czechia lags the European Union average, which is

${ }^{8}$ Adriana Ondrušová, Students and Graduates of Universities and Colleges in the Czech Republic, [Studenti a absolventi vysokých a vyšších odborných škol v České republice] Czech statistical Office, 2020, https://www.czso.cz/csu/czso/studenti-a-absolventi-vysokych-avyssich-odbornych-skol-v-cr-2018.

9 Transition of High School Graduates to Tertiary Education - 2017/18, [Přechod absolventů středních škol do terciálního vzdělávání - 2017/18] National institute for education, accessed June 22, 2020. https://www.infoabsolvent.cz/Temata/PublikaceAbsolventi?Stran $\mathrm{ka}=9-0-152$.

${ }^{10}$ Adriana Ondrušová, "Students and Graduates of Universities and Colleges in the Czech Republic," Czech statistical Office, 2020, https://www.czso.cz/csu/czso/studenti-a-absolventivysokych-a-vyssich-odbornych-skol-v-cr-2018. 
higher by 6.4 percentage points. ${ }^{11}$ These facts put pressure on current universities in a competitive environment. Table 1 shows development of the total number of students in the Czech Republic by sex and nationality in selected years.

Table 1

Development of the number of students in the Czech Republic

\begin{tabular}{|l|c|c|c|c|c|c|c|c|c|}
\hline \multicolumn{1}{|c|}{ Year } & 2001 & 2005 & 2010 & 2015 & 2016 & 2017 & 2018 & 2019 & 2020 \\
\hline $\begin{array}{l}\text { *Total } \\
\text { university } \\
\text { students }\end{array}$ & 203.4 & 289.5 & 396.0 & 326.4 & 311.1 & 298.7 & 289.7 & 288.6 & 299.4 \\
\hline Female (\%) & 48.3 & 52.1 & 55.9 & 55.8 & 56.0 & 56.1 & 55.9 & 55.8 & 55.5 \\
\hline $\begin{array}{l}\text { Foreigners } \\
\text { (\%) }\end{array}$ & 4.3 & 7.2 & 9.5 & 12.9 & 14.0 & 14.6 & 15.4 & 16.1 & 16.7 \\
\hline
\end{tabular}

(*in thousands of persons)

Source: Czech statistical office, https://www.czso.cz/csu/czso/studenti-a-absolventi-vysokychskol-v-ceske-republice-2020

The only way to strengthen competitiveness is to constantly improve quality and thus support the growth of one's image in the eyes of the public. Dimitrivova G. and Dimitrivova V. came to similar conclusions in 2017. ${ }^{12}$ Khairunnisa and Krisnawati show that brand awareness is the most influential factor in strategic competitiveness, however, service quality and factors related to service quality need to be constantly improved..$^{13}$ Even though there are several international rankings and the rankings of the Czech media, which, according to various criteria, compare individual universities or colleges, the most important view is still insufficiently processed, namely the view of students.

${ }^{11}$ Education - Analysis, Comments, [Vzdělávání - Analýzy, komentáře] Czech statistical Office, August 28, 2019, https://www.czso.cz/csu/czso/vzdelavani-analyzy-komentare. statistical Office.

${ }^{12}$ G. Dimitrova and T. Dimitrova, "Competitiveness of the Universities: Measurement Capabilities," Trakia Journal of Science 15, no. Suppl.1 (2017): pp. 311-316, https://doi. org/10.15547/tjs.2017.s.01.055.

${ }_{13}$ Khairunnisa Khairunnisa and Nila Krisnawati, "The Emergence of Service Quality and Brand Awareness toward Strategic Competitiveness and Its Impact on Hotel Performance," Journal of Business on Hospitality and Tourism 1, no. 1 (2015): p. 16, https://doi.org/10.22334/ jbhost.v1i1.22. 


\section{II.1. Quality in higher education}

Quality assurance in higher education represents a basic priority of this educational sphere. The approaches to quality in education vary from country to country. The education is affected by the political, economy, religion, and cultural factors of every country. Quality of education is totally depending upon the policies of Government. By the authors there financial, religious, and cultural issues are the main causes of different in the education system. Despite significant efforts to converge approaches to quality assurance in higher education in Europe, individual nation states and their policies continue to play a primary role. However, responsibility for the quality of higher education is being increasingly transferred to the individual universities themselves that at the same time does not remove the role of the state as a determining operator, but shifts the emphasis from external evaluation (e.g., accreditation) to institutionalized internal evaluation. It is necessary to focus not only on the area of goals, standards, rules, and criteria, but also on the processes that will enable these goals to be achieved. The quality management system as a part of university management contributes to the creation of a transparent and standardized management system that perceives the requirements of clients of university stakeholders and creates an environment for their fulfillment - ensuring the quality of higher education. ${ }^{14}$ At the beginning of the 20th century, the quality of higher education in the United States began to be assessed through rankings but the boom in their use has only occurred in recent years of the 21 th century throughout the world. The most well-known of these are Academic Ranking of World Universities (ARWU), Times Higher Education World University Rankings (THE), QS World University Rankings (QS), and Multirank. Rankings are created not only at the global and European level, but also at the level of individual countries, where their creators are media or research institutions. The emergence of rankings is justified by the increasing competition between the world's universities, but it should be noted that the rankings themselves contribute to the intensification of competition. ${ }^{15}$ Some articles and publications have been written on the problematic relationship between rankings and quality.

${ }^{14}$ Milan Hutyra, "The Way from Quality Management System to Excellence at the University Environment, " February 15, 2008, https://ep.liu.se/en/conference-article.aspx?serie $\mathrm{s}=$ ecp\&issue $=26 \&$ Article_No=126.

${ }^{15}$ Gero Federkeil, "Rankings and Quality Assurance in Higher Education," Higher Education in Europe 33, no. 2-3 (September 1, 2008): pp. 219-231, https://doi.org/10.1080/ 03797720802254023. 
Ellen Hazelkorn who is one of the most significant experts regarding the quality and rankings of universities and their influence on the development of individual institutions and the entire higher education system, recommends universities to have a realistic strategy and use rankings only as part of an overall system of evaluation or benchmarking as well as providing quality public information about their results. ${ }^{16}$ According to Kurbatov rankings are becoming a kind of condensed guideline for university managers on how to reform the university in connection with the creation of a world university within the main trends of academic development of our time. ${ }^{17}$ Quality assurance of universities and objective quality assessment is a real and open question today. According to Štefánková and Moravčík this issue is in the center of attention of to all developed and developing countries, which combine their planned economic and educational future with a modern, efficient system of higher education. Today's world is dominated by a generally accepted and recognized system of evaluation and assessment of the Anglo-Saxon environment, which is largely determined by scientific indicators. ${ }^{18}$ Researchers from all over the world are interested in the quality of higher education. According to Chui and Ahmad, in search of academic excellence, the Malaysian government is very concerned about the quality of universities. Their study evaluates the quality of services of a Malaysian private university to identify significant variables in education services. ${ }^{19}$ In turn, it draws attention to the problems of Indian universities that do not have a chance of reaching the global rankings due to lack of tradition, small size, and insufficient funding. ${ }^{20}$ Karadag and Yücel examined the satisfaction of 10,894 students at 174 Turkish universities to increase the

16 Ellen Hazelkorn, "The Dubious Practice of University Rankings," Elephant in the Lab (Elephant in the Lab, April 23, 2019), https://elephantinthelab.org/the-accuracy-of-universityrankings-in-a-international-perspective/.

17 Sergiy Kurbatov, "University Rankings and the Problem of Competitiveness of National Universities of Post-Soviet Countries in Global Educational Space: the Case of Ukraine," Evaluation in Higher Education 6, no. 2 (December 1, 2012): p. 59-75, https://doi. org/ 10.6197/EHE.2012.0602.04.

18 Jana Štefánková and Oliver Moravčík, "An Approach to the Quality Assessment of Higher Education Institutions via Knowledge Management Principles," DSpace Home page (Academic Publishing International (API), January 1, 2012), https://publikace.k.utb.cz/ handle/10563/1003104.

19 Teo Boon Chui et al., "Evaluation of Service Quality of Private Higher Education Using Service Improvement Matrix," Procedia-Social and Behavioral Sciences 224 (June 15, 2016): pp. 132-140, https://doi.org/10.1016/j.sbspro.2016.05.417.

20 Pankaj Jalote, "India's Quest for World-Ranked Universities," Current Science 16, no. 9 (May 2019): pp. 1479-1482, https://doi.org/10.18520/cs/v116/i9/1479-1482. 
competitiveness of universities. According to their finding, providing support to students and responding to their needs is more important when choosing a university than the number of scientific publications. ${ }^{21}$

\section{II.2. Increasing competitiveness (international comparison of universities)}

Over the last decade the ranking of universities has become an extremely popular and "fashionable" topic for general discussions as well as for academic research. As Hazelkorn stated in her book: "There is a growing obsession with university rankings around the world". ${ }^{22}$ Mossa also talks about the problematic criteria of global rankings, as he does not deal much with teaching and the quality of such, which should be given the same importance as research. ${ }^{23} \mathrm{~A}$ similar view is shared by Shin, who also criticizes the idea of evaluation and the existing methodology for assessing the quality of university performance..$^{24}$ Other authors state that since the creation of global rankings, it has been impossible for universities to ignore various national and international comparisons. Involvement in rankings is changing and, in some respects, improves the performance of universities. ${ }^{25,26}$ Similarly, Avralev and Efimova note that global rankings are employed to reconstruct higher education and contribute to an increase in the competitiveness of Russian universities on the world stage. ${ }^{27}$ One of the many uses of the

${ }^{21}$ Engin Karadağ and Cemil Yücel, “(PDF) Türkiye Üniversite Memnuniyet Araştırması [Tüma-2016],” accessed October 6, 2021, https://www.researchgate.net/publication/ 305207486_Turkiye_Universite_Memnuniyet_Arastirmasi_TUMA-2016.

${ }^{22}$ Ellen Hazelkorn, Rankings, and the Reshaping of Higher Education: The Battle for World-Class Excellence (Basingstoke: Palgrave Macmillan, 2015).

${ }^{23}$ Raazia Moosa, "World University Rankings: Reflections on Teaching and Learning as the Cinderella Function in the South African Higher Education System," African Journal of Business Ethics 12, no. 1 (June 26, 2018): pp. 38-59, https://doi.org/10.15249/12-1-165.

${ }^{24}$ Jung Cheol Shin, Robert Kevin Toutkoushian, and Ulrich Teichler, University Rankings: Theoretical Basis, Methodology, and Impacts on Global Higher Education (Dordrecht: Springer, 2013).

${ }^{25}$ Evija Rusite and Biruta Sloka, "Importance of Collaboration with Employers towards the Rankings of Higher Education Institutions," 20th International Scientific Conference "Economic Science for Rural Development 2019". New Dimensions in the Development of Society. Home Economics. Finance and Taxes. Bioeconomy., May 8, 2019, https://doi. org/10.22616/esrd.2019.113.

26 Jalote, Pankaj. "India's quest for world-ranked universities." Current Science 116.9 (2019): 1479. https://doi.org/10.6017/ihe.2019.99.11659.

${ }^{27}$ Nikita Avralev and Irina Efimova, "University Rankings as a Tool for Assessing the Quality of Education in the Context of Globalization," Asian Social Science 11, no. 10 (2015): p. 292, https://doi.org/10.5539/ass.v11n10p292. 
ranking system can be seen in providing information helpful for making university selection decisions. ${ }^{28,29}$

The high ranking has a strong impact on students when making decisions about choosing the appropriate university. ${ }^{30}$ Dearden created a theoretical model characterizing the relationship between the university and potential students, who can use the ranking to decide which university they wish to attend. In addition, they asked students which rankings would better suit their preferences. ${ }^{31}$

Several studies aim to examine the world's leading university rankings and to identify similarities and differences in their evaluation criteria, key indicators, modelling options and their effects on rankings. A comparison of the rankings of universities according to the world's leading ranking systems shows that in some cases the university may be at the top level and in others it may not be ranked at all. This is because some ranking systems use hard data and some soft data. Another important problem in terms of the diversity of indicators is that the two most important functions of a university, research, and teaching, are measured together in quality assessment. Research data shared by universities has also been shown to raise concerns about credibility and authenticity. It is also clear that subjective evaluation tools can lead to erroneous results. ${ }^{32,33}$ In their paper, Luca and Smith point out that most universities that publish evaluation rankings conceal some details. Although the reports are of high quality and fully verifiable, companies can choose how to present the result. ${ }^{34}$

${ }^{28}$ Ronald G. Ehrenberg, "Reaching for the Brass Ring: The US News \&amp; World Report Rankings and Competition," The Review of Higher Education 26, no. 2 (2003): pp. 145162, https://doi.org/10.1353/rhe.2002.0032.

${ }^{29}$ Simon Marginson, "Global University Rankings: Implications in General and for Australia," Journal of Higher Education Policy and Management 29, no. 2 (April 8, 2008): p. 131-142, https://doi.org/10.1080/13600800701351660.

${ }^{30}$ Nicholas A. Bowman and Michael N. Bastedo, "Getting on the Front Page: Organizational Reputation, Status Signals, and the Impact of U.S. News and World Report on Student Decisions," Research in Higher Education 50 (February 24, 2009): pp. 415-436, https://doi.org/10.1007/s11162-009-9129-8.

31 James A. Dearden, Rajdeep Grewal, and Garry L. Lilien, "Strategic Manipulation of University Rankings, the Prestige Effect, and Student University Choice," Journal of Marketing Research 56, no. 4 (May 30, 2019): pp. 691-707, https://doi.org/10.1177/0022243719831258.

32 Gokcen Arkali Olcay and Melih Bulu, "Is Measuring the Knowledge Creation of Universities Possible? A Review of University Rankings," Technological Forecasting and Social Change 123 (October 2017): pp. 153-160, https://doi.org/10.1016/j.techfore.2016.03.029.

${ }^{33}$ Osama H. Sayed, "Critical Treatise on University Ranking Systems," Open Journal of Social Sciences 07, no. 12 (2019): pp. 39-51, https://doi.org/10.4236/jss.2019.712004.

${ }^{34}$ Michael Luca and Jonathan Smith, "Strategic Disclosure: The Case of Business School Rankings," Journal of Economic Behavior \& Organization 112 (2015): pp. 17-25, https://doi. org/10.1016/j.jebo.2014.12.023. 
Therefore, many authors claim that global rankings are wrong, which is why some universities ignore them and propose their own metrics. ${ }^{35,36,37,38}$ However, as Readings said, evaluation should be seen as a certain innovative technology that is forcing dramatic changes in higher education in the context of globalization and increasing the level of competitiveness. ${ }^{39}$

\section{II.3. Surveys on important factors of higher education institution quality}

Research to date has shown that most colleges and universities worldwide use teacher assessment as the primary method of teacher and teaching evaluation, and that this evaluation is a permanent part of educational quality measurement programs. ${ }^{40,41}$ Marsh and Roch contradict the opinion when discovering the views and opinions of students can be very beneficial for the quality of teaching. ${ }^{42}$ Other authors deal with the identification of factors influencing the choice of a university and therefore affecting its image and the perception of its quality. For example, Connie et al. in a sample of 90 respondents looked at relevant factors that could influence universities students in choosing a university and provide a higher education institution with a clear picture of the area it should focus on in its strategy. Their results

${ }^{35}$ Farzana Anowar et al., "A Critical Review on World University Ranking in Terms of Top Four Ranking Systems," Lecture Notes in Electrical Engineering, August 2014, pp. 559566, https://doi.org/10.1007/978-3-319-06764-3_72.

${ }^{36}$ Soh Kaycheng, "What the Overall Doesn't Tell about World University Rankings: Examples from ARWU, QSWUR, and THEWUR in 2013," Journal of Higher Education Policy and Management 37, no. 3 (May 5, 2015): pp. 295-307, https://doi.org/10.1080/136008 0X.2015.1035523.

${ }^{37}$ Dyah Kusumastuti and Nirwan Idrus, "Nurturing Quality of Higher Education through National Ranking: A Potential Empowerment Model for Developing Countries," Quality in Higher Education 23, no. 3 (2017): pp. 230-248, https://doi.org/10.1080/13538322.2017.1407400.

${ }^{38}$ Brendan O’Malley, “'Global University Rankings Data Are Flawed' - HEPI," University World News, December 15, 2016, https://www.universityworldnews.com/post. php?story $=20161215001420225$.

${ }^{39}$ Bill Readings, The University in Ruins (Cambridge, Mass: Harvard University Press, 1999).

${ }^{40}$ Yining Chen and Leon B. Hoshower, "Student Evaluation of Teaching Effectiveness: An Assessment of Student Perception and Motivation," Assessment \& Evaluation in Higher Education 28, no. 1 (2003): pp. 71-78, https://doi.org/10.1080/02602930301683.

${ }^{41}$ John T.E. Richardson, "Instruments for Obtaining Student Feedback: A Review of the Literature," Assessment \& Evaluation in Higher Education 30, no. 4 (September 14, 2010): pp. 387-415, https://doi.org/10.1080/02602930500099193.

${ }^{42}$ Herbert W. Marsh and Lawrence A. Roche, "Effects of Grading Leniency and Low Workload on Students' Evaluations of Teaching: Popular Myth, Bias, Validity, or Innocent Bystanders?" Journal of Educational Psychology 92, no. 1 (2020): pp. 202-228, https://doi. org/10.1037/0022-0663.92.1.202. 
suggest that there is a positive relationship between a group of factors such as the program, the reputation of the university, job opportunities, tuition fees, safety, school equipment and the possibility of having fun, with the choice of university. ${ }^{43}$ Sabando, et al. consider the factors with the greatest influence on the image of the university. The survey involving a total of 1,760 respondents selected from five stakeholder samples (society, future students, current students, graduates and companies), found that although some differences between stakeholders were observed, an affective image, perceptions of teaching resources and perceptions of graduate training significantly influence the formation of the overall image of the university from the point of view of society and that the structure of the image identified from this point of view is shared by companies. ${ }^{44}$ The quality of higher education does not merely focus on teaching and learning processes and on the relationship between students and teachers but must also be ensured through services provided by university libraries, cafeterias, university refectories, social services, and central administrative services.$^{45}$ Similarly, the quality of services is a critical element of the perception of clients, including students. ${ }^{46}$ In recent years, most universities in developed countries consider continuing to support the care of students with special educational needs as one of their priorities and seek to equalize study opportunities for applicants and students with various types of disabilities or disadvantages.

The dimensions of service quality were determined through pioneering research by Zeithaml and Binter, who created a conceptual framework explaining service quality in relation to five dimensions. These five dimensions are reliability, certainty, sensitivity, empathy, and tangibility. ${ }^{47}$

${ }^{43}$ Connie Gan et al., "Exploring Key Factors Influencing University Choice: An Empirical Study on Malaysia Students," 1st International Digital Conference on Modern Business and Social Science, December 13, 2018, https://doi.org/10.13140/RG.2.2.16662. 80962.

${ }^{44}$ Amaia Lafuente Ruiz de Sabando, Javier Forcada, and Pilar Zorrilla, "The University Image: A Model of Overall Image and Stakeholder Perspectives," Management Letters Cuadernos De Gestión 19, no. 1 (2019): pp. 63-86, https://doi.org/10.5295/cdg.160720al.

${ }^{45}$ Sandra Maria Correia Loureiro and Francisco Javier Miranda Gonzalez, "DUAQUAL: The Quality Perceived by Teachers and Students in University Management.," Cuadernos De Gestión 12, no. 1 (2012): pp. 107-122, https://doi.org/10.5295/cdg.100251sc.

46 Janardhana Gundla Palli and Rajasekhar Mamilla, "Students' Opinions of Service Quality in the Field of Higher Education," Creative Education 3, no. 4 (August 10, 2012): pp. 430-438, https://doi.org/10.4236/ce.2012.34067.

${ }^{47}$ Valarie A. Zeithaml, Mary Jo Bitner, and Dwayne D. Gremler, "Services Marketing: Integrating Customer Focus Across the Firm - 7th Ed.," Thư viện số Văn Lang: Trang chủ (McGraw-Hill Education, January 1, 1970), http://thuvienso.vanlanguni.edu.vn/handle/ Vanlang_TV/19151. 


\section{II.4. Czech universities in international rankings}

Czech universities belong among the 1000 best universities in the world. According to the currently published QS World University Rankings 2021, the best position, as in previous years, was secured by Charles University, which finished in 260th place. In addition, for example, the Institute of Chemical Technology, the Czech Technical University, Masaryk University, Palacky University in Olomouc, and Mendel University in Brno are placed in the rankings. Mendel University was ranked in 701-750th place, like Brno University of Technology. Among agricultural Czech universities, MENDELU is rated the best. ${ }^{48}$ "The evaluation in each set of rankings offers us an important comparison with other universities and increases the prestige of MENDELU in an international context. That is also the reason why we took part in this evaluation," said Nerudova, the Rector of Mendel University in Brno. She states that similar rankings give the university a feedback to find weaknesses, and what should be improved in the coming years. ${ }^{49}$ This ranking evaluates 6 areas, with a total of $50 \%$ of evaluations being its reputation among academics and graduate employers, $20 \%$ the number of citations in the Scopus database, $20 \%$ the share of foreign academics and 5\% the share of foreign students. The Academic Assessment of World Universities (ARWU) has been published since 2009 in the Czech Republic, with only Charles University appearing in it. Another of the three respected university rankings is The Times Higher Education World University Rankings 2020 (THE). Four Czech universities have maintained their places in the new THE rankings for 2020. The best of them - Charles University is in 401st -500 th position, followed by Masaryk University and Palacky University (601st - 800th place) while CTU together with the University of South Bohemia, which has appeared in the rankings for the first time this year, came in at 801st-1000th position. Mendel University and the University of Hradec Kralove, which are ranked in 1000+ position, have also recently been added to the rankings (THE university ranking, 2020)..$^{50}$ U-Multirank, which is formed by an independent consortium, can also be included in the traditional international ranking systems. Its aim is to provide a comparison of higher education institutions based on many individually

48 “QS World University Ranking 2021,” Top Universities, accessed June 30, 2020, https://www .topuniversities.com/universities/country/czech-republic.

${ }^{49}$ Mendelu among the Best Schools in the World, [Mendelu mezi nejlepšími školami světa] Mendel University in Brno, accessed June 23, 2020. http://mendelu.cz/32873n-mendelumezi-nejlepsimi-skolami-sveta.

50 "World University Rankings," Times Higher Education (THE) online, February 11, 2020, https://www .timeshighereducation.com/world-university-rankings/2020/worldranking\#!/page/0/length/25/sort_by/rank/sort_order/asc/cols/stats. 
selected parameters. In addition to the five basic categories (teaching, research, knowledge transfer, internationalization, and regional involvement) and their 36 subcategories, in which individual institutions obtain marks from A - E, it is possible to classify according to countries, disciplines and general characteristics, such as the size or age of the institution. This year's seventh edition includes 1,759 universities from 92 countries, including 15 Czech universities. The Czech institutions with the highest number of positions in the upper group (mark A) in U-Multirank 2020 include the University of Chemistry and Technology (Prague, mark 11 A), Tomas Bata University in Zlín (8), Mendel University in Brno (7) and the Institute of Technology and Business in České Budějovice (6). ${ }^{51}$

\section{Research objective, methodology, and data}

The aim of the work is to verify what factors are important regarding students' satisfaction and could be key to supporting the competitiveness of Czech universities and colleges. To assess satisfaction, a questionnaire survey was conducted in 2019, in which students were asked to identify three strengths and three weaknesses of the faculty. Due to the fact that students mentioned only 3 strengths and 3 weaknesses of the faculty, alternatively their gender and age, it is not necessary to insert a questionnaire in the appendix. The questionnaire did not contain any other questions. Therefore, there was no need to create a pilot study. All bachelor's students from both universities were made aware of the possibility participating in the survey on Facebook pages by researchers. Participation was voluntary. Students were also informed that they could terminate their participation in the research at any time and that the information they provided would not be used against them. The survey was carried out within the Faculty of Business and Economics of Mendel University in Brno (FBE MENDELU) and a selected private university in Brno. A total of 340 bachelor's students, aged 21-23, participated in the research at FBE MENDELU. Of these, 122 were men (35.9\%) and 218 women (64.1\%). No foreign students participated in the research. We accepted a margin error of $5 \%$, with the confidence level $95 \%$ and with the response distribution $50 \%$. In 2019, 1,852 students studied at PEF MENDELU. Then the recommended sample size is 319. 340 respondents are therefore a sufficient number. A total of 255 bachelor's students, aged 21-23, were involved in the selected private school survey. Of

51 “Multirank: Universities Compared. Your Way.," U, accessed October 23, 2020, https:// www .umultirank.org/compare?trackType $=$ compare \&sightMode=undefined\&section=compareS ubject $\&$ mode $=$ likewithlike $\&$ instutionalField $=$ true $\&$ pref $-4=3 \&$ country $=42 \&$ count $\&$ name $=$ null . 
these 124 were men (48.6\%) and 131 women $(51.4 \%)$. No foreign students participated in the research. We also accepted a margin error of 5\%, with the confidence level $95 \%$ and with the response distribution $50 \%$. In 2019, 721 students studied at selected private school. Then the recommended sample size is 251.255 respondents are therefore also a sufficient number. The students from both universities had the opportunity to put their answers in the prepared boxes. Simple questionnaires were placed next to the answer box. No answer could be attributed to a specific person. Students provided their opinions voluntarily. They had the opportunity to state gender and age on the questionnaire. (However, this information did not need to be provided). The subject of our research was not the collection of personal data, and the output of the research project was not the details of the individual. Students were informed that their answers are anonymous and will only be used for a scientific article. Because each of the universities has several thousand students, it was not possible to determine the specific affiliation of those who participated in the survey. The researchers considered the content of the questions to be so general that there was no risk of harm to the participants in answering them. Due to the fact that the questions did not contain absolutely any personal data of students, according to the GDPR, consent to their processing was not required.

Relative frequencies are used in data processing. Based on this characteristic, statistical hypotheses were tested. In addition to the basic classification according to one feature, a combination classification was also processed, and the independence was tested for different combinations of questions. The independence in the table was tested with the test. The test criterion is:

$$
\chi^{2}=\sum_{j=1}^{s} \sum_{i=1}^{r} \frac{\left(n_{i j}-n_{i j}^{\prime}\right)^{2}}{n_{i j}^{\prime}}
$$

with degrees of freedom. If the calculated criterion is greater than the critical quantile, we reject the hypothesis of independence between the characters and therefore the existence of a relationship can be assumed. In addition to the test the article also uses single-sample and multi-sample testing of relative frequency. Test criterion

$$
U=\frac{p-c}{\sqrt{\frac{c(1-c)}{n}}} \text { and } U=\frac{p_{1}-p_{2}}{\sqrt{\frac{\left(n_{1} \cdot p_{1}+n_{2} \cdot p_{2}\right) \cdot\left(n-n_{1} \cdot p_{1}-n_{2} \cdot p_{2}\right)}{n \cdot n_{1} \cdot n_{2}}}}
$$

in both cases it has an approximately normalized standard distribution. In the case of a one-sample test, we test the null hypothesis of concordance of relative frequency with some assumption, in the case of two-sample testing, 
we test the hypothesis of concordance of relative frequencies. ${ }^{52}$ Gretl and Statistica software was used for primary data processing.

As part of the specification of the research, the authors defined 4 hypotheses:

$\mathbf{H}_{\mathrm{A}}$ : More than $50 \%$ of students identify quality teachers as a strength.

$\mathbf{H}_{\mathbf{B}}$ : The number of students who emphasize the interest of lectures and teaching methods is higher in private schools than in public schools.

$\mathbf{H}_{\mathbf{C}}$ : There is a statistically significant difference in the identified strengths of the school from a gender perspective (male, female).

$\mathbf{H}_{\mathrm{D}}$ : There is a statistically significant difference between the identified strengths of public and private university students.

\section{Results and discussion}

\section{IV.1. Selected elements of internal quality assessment at Mendel University in Brno}

The implementation of the quality management system has been under way at Mendel University in Brno (MENDELU) since 2016. Its mission is to create conditions for fulfilling quality goals and ensure continuous improvement in all areas of the university's activities based on defined quality requirements. An annual internal quality assessment started at MENDELU in 2017. Since 2018, some elements of feedback have been newly added to the quality management system. These focus on four target groups, namely employees, students, graduates, and employers of graduates. Students and employees have the opportunity to evaluate satisfaction with the services of the faculty and rector's and university-wide workplaces in the form of anonymous questionnaires, as well as to express their expectations, comments, and experiences, thanks to which it is possible to identify suggestions for improvement and possible corrective measures. Regularly implemented feedbacks include anonymous evaluation of the level of teaching individual subjects from the students' point of view, as well as feedback from graduates through a questionnaire survey. ${ }^{53}$ In 2019 , in response to a question about memories of studying, positive memories emerged most often, such as establishing new friendships and fair and

${ }^{52}$ Richard Hindls et al., Statistics for economists, [Statistika pro ekonomy] (Průhonice, Czech Republic: Professional publishing, 2007).

${ }^{53}$ Quality and risk department, "Mendel University in Brno," Home page - Quality and Risk Department, accessed June 23, 2020, https://kvalita.mendelu.cz/. 
accommodating teachers. Graduates also appreciated the prestige of the faculty, which has high demands, but also provides a very high level of education. Thus, the high demands were not perceived negatively by the respondents. Among the negative memories, the most common were stress and lack of practical training, hard work, little free time, and the pointlessness of some subjects.

\section{IV.2. Results of the questionnaire survey at FBE MENDELU}

Of the total number $(1,020)$ of identified strengths, $57.7 \%$ of students mentioned quality teachers as a strength, $32.4 \%$ faculty image, $31.8 \%$ modern environment, $20.9 \%$ campus facilities, $17.7 \%$ Erasmus travel opportunities, $17.1 \%$ faculty location, $15.0 \%$ lectures by practitioners, $14.1 \%$ the university's tradition, $12.4 \%$ high employment of graduates and over $10 \%$ of students also mentioned as a strength the opportunity to study attractive fields $(11.8 \%)$. When testing the concurrence of the relative frequency between male and female students, there was no statistically significant difference for any factor. Thus, it can be said that the individual factors are at approximately the same percentage level for both male and female students from the point of view of the opinion that this is a strong point. The 10 most frequently mentioned strengths by gender are documented in Figure 1.

Regarding the identified weaknesses, out of the total number $(1,020)$, the difficulty of study was most often mentioned $42.4 \%$, the weaker image of the university with the public $31.5 \%$, not enough practical training $23.2 \%$, poor quality food in the canteen $15.3 \%$, location $13.8 \%$, small capacity of classrooms and study rooms $13.5 \%$, chaotic university information system (UIS) and problems with technology $13.5 \%$ and up to $10 \%$ of students still stated low scholarships $(11.5 \%)$. When testing the concurrence of the relative frequency between male and female students, there was no statistically significant difference for any factor. Thus, it can be said that the individual factors are at approximately the same percentage level for male and female students from the point of view of the opinion that this is a weakness. The 10 most frequently mentioned weaknesses by gender are documented in Figure 2 .

If we consider as the most important strengths and weaknesses of the faculty the one mentioned by the students first, then the 3 most important strengths are quality teachers $(22.9 \%$ students, $23.0 \%$ male and $19.8 \%$ female), modern environment (11.8\% students, $6.6 \%$ male and $14.7 \%$ female) and the image of the faculty (9.4\% of students, $12.3 \%$ male and $7.8 \%$ female). The 3 most important weaknesses are not enough practical training (15.6\% of students, $10.7 \%$ male and $18.4 \%$ female), difficulty of 
study (15.0\% of students, $18.9 \%$ male and $12.8 \%$ female) and chaotic UIS ( $10.6 \%$ of students, $13.1 \%$ male and $9.2 \%$ female). No other combination of strengths and weaknesses had a frequency above 10 students. Research shows that students' views on the most important strengths and weaknesses differ significantly. If we consider the common strengths and weaknesses regardless of the order, then 87 students had in their questionnaire a combination of quality teachers as a strength and difficulty of study as a

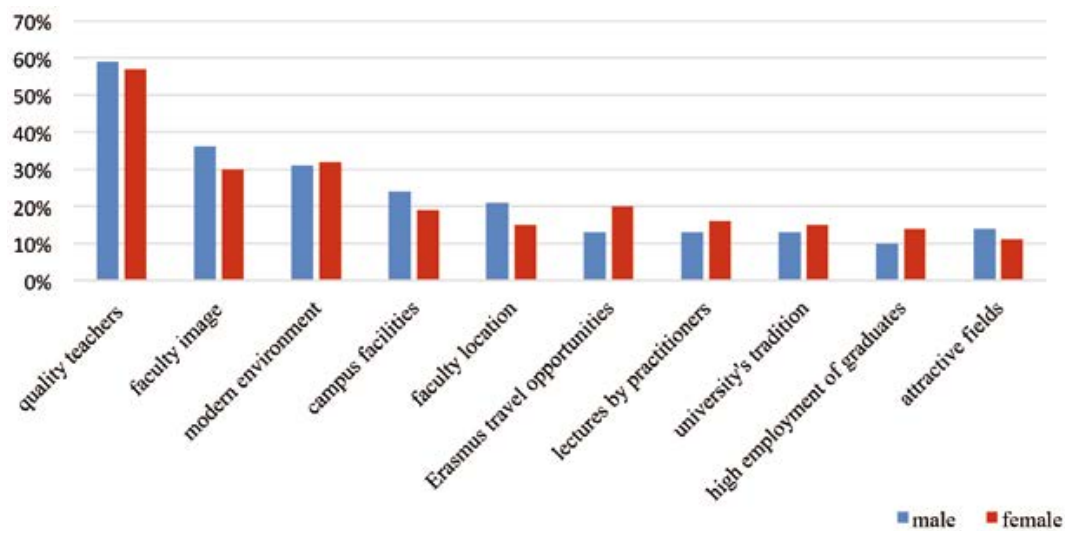

Figure 1

10 strengths by genders at FBE MENDELU

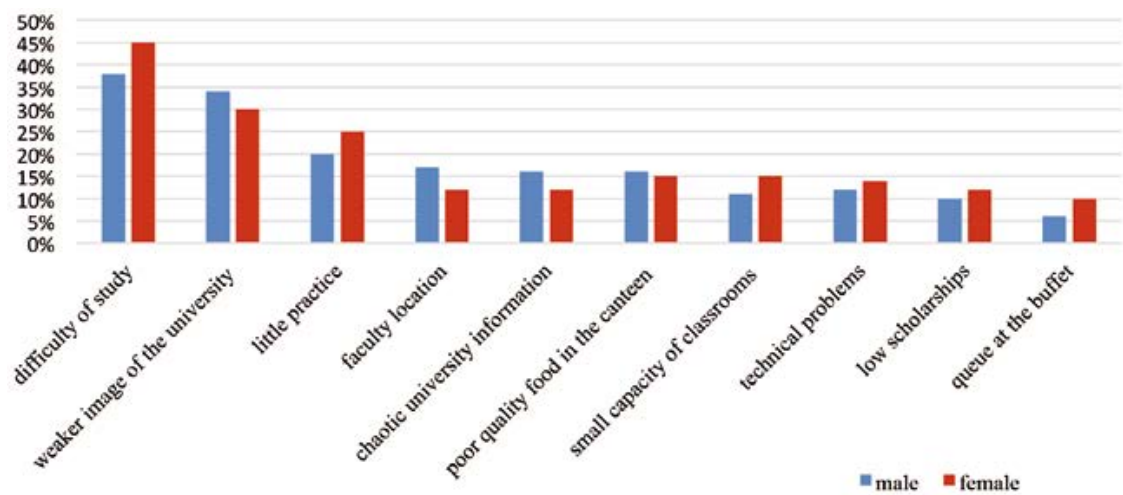

Figure 2

10 weaknesses by genders at FBE MENDELU 
weakness. The second highest number was for a combination of quality teachers and a weaker image perceived by the public (59) and the third for quality teachers and not enough practical training (52 students). For 62 female students, it was a combination of quality teachers and the difficulty of studying, for 39 a combination of quality teachers and not enough practical training and for 34 quality teachers and too many students. For male students, the most common combination ( 25 male students) was quality teachers and difficulty of study, quality teachers and a weaker image perceived by the public (20 male students) and then a good image and difficulty of study and at the same time quality teachers and not enough practical training (18 male students).

\section{IV.3. Results of a questionnaire survey for a private university}

Students identified a total of 765 strengths. Almost half of the respondents stated that the school's strengths are quality pedagogical staff (47.8\%). Among other significant strengths, students mentioned interesting lectures and teaching methods $40.8 \%$, study materials for subjects $29.41 \%$, offers of interesting subjects $25.10 \%$, pleasant atmosphere $18.0 \%$, attractive fields $14.9 \%$, location $14.9 \%$, possibility of consultations $11.8 \%$, study department - willingness to help students $11.4 \%$, a well-established schedule $11.0 \%$, and an individual approach to students $10.2 \%$. When testing the concurrence of the relative frequency between male and female students, a statistically

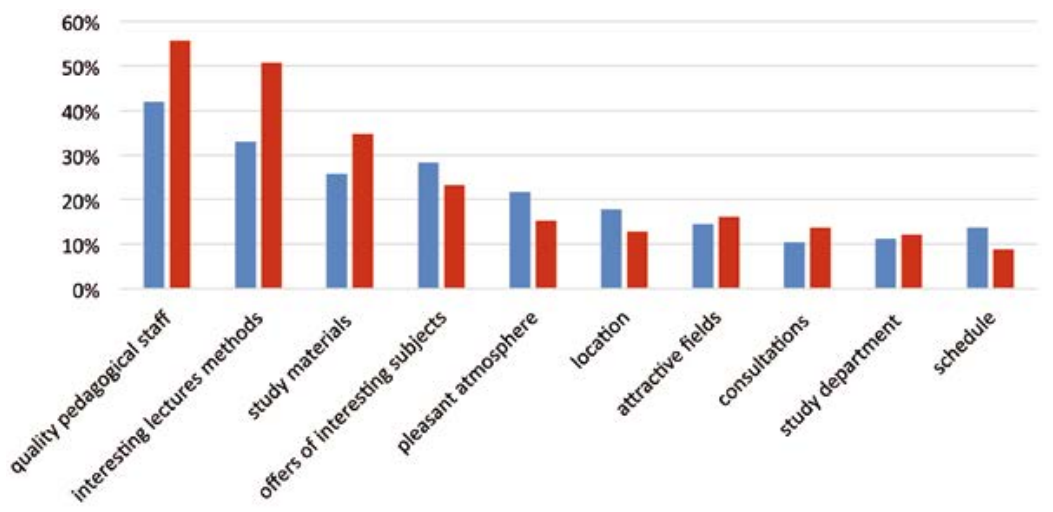

male female

Figure 3

10 strengths by genders at selected private school 


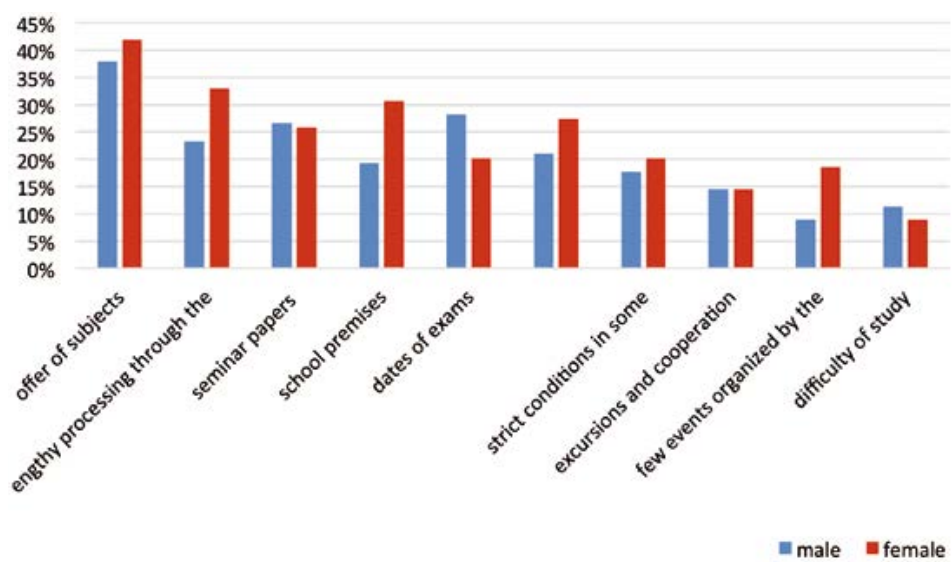

Figure 4

10 weaknesses by genders at selected private school

significant difference was found only in the interesting lecture and teaching method and quality teachers. For the test with the hypothesis that a higher percentage of female than male students consider it a strength, the p-value was 0.007 . On the other hand, a larger percentage of male students see quality teachers as a strength (statistically significant difference, $\mathrm{p}$-value $0.005)$. It can be stated that other factors are at approximately the same percentage level for male and female students from the point of view of the fact that it is a strength. The 10 most frequently mentioned strengths by gender are documented in Figure 3.

Among the weaknesses, students most often identified the offer of subjects (38.8\%), lengthy processing through the study department $27.5 \%$, a large number of seminar papers $25.5 \%$, insufficient capacity of school premises $24.3 \%$, problems with technology and wifi in classrooms $23.5 \%$, unsatisfactory form and dates of exams $23.5 \%$, strict conditions in some subjects $18.4 \%$, narrow offer of excursions and cooperation $14.1 \%$, few events organized by the school $13.3 \%$. The 10 most frequently mentioned weaknesses by gender are documented in Figure 4.

In their questionnaire, 52 students had a combination of quality teachers as a strength and the range of subjects as a weakness. The second highest number was in the combination of interesting lectures and a weaker offer of subjects (26) and the third in the case of quality teachers and lengthy processing through the study department (22 students). For female students, the following combinations of strengths and weaknesses are most common: 
quality teachers + offer of courses (23), interesting lectures + offer of courses (20), quality teachers + lengthy processing through the study department (13), interesting lectures + lengthy processing through the study department (13). In male students, the following combinations of strengths and weaknesses are most common: quality teachers + offer of subjects (29), interesting lectures + many seminar papers (10), no other combination showed a frequency greater than 10 among male students.

\section{IV.4. Evaluation of hypotheses}

$\mathbf{H}_{\mathrm{A}}$ : The relative frequency test was used to test $\mathrm{H}_{\mathrm{A}}$ (see Table 2). For the purposes of evaluating this research question, the answers of the respondents were divided into two groups according to their affiliation to the selected school (FBE MENDELU, private university). It was also tested at each of the schools as to how this issue was evaluated by female and male respondents.

As documented in Table 2, we then rejected the null hypothesis for students from FBE MENDELU (this also applies to individual genders). Based on the test, it can be said that more than 50\% of FBE MENDELU students identified quality teachers as a strength. For students from the private university, the null hypothesis was not rejected, and therefore, based on testing, it was not proven that a quality teacher is identified as a strength by more than $50 \%$ of students.

Table 2

Relative frequency test results

\begin{tabular}{|l|c|c|}
\hline \multicolumn{1}{|c|}{ Group of students } & Test criterion & p-value \\
\hline FBE MENDELU students & 2.821 & 0.002 \\
\hline Female & 2.032 & 0.021 \\
\hline Male & 1.992 & 0.023 \\
\hline Private university students & -0.814 & 0.208 \\
\hline Female & -2.359 & 0.009 \\
\hline Male & 1.257 & 0.104 \\
\hline
\end{tabular}

$H_{0}: \pi \leq 0,5$; Level of significance $a=0.05 ; H_{1}: \pi>0,5$.

$\mathbf{H}_{\mathrm{B}}$ : The number of students who emphasize the interest of lectures and teaching methods is higher in private schools than in public schools. 


$$
U=\frac{0,29-0,07}{\sqrt{\frac{(104+24) \cdot(595-104-24)}{595 \cdot 255 \cdot 340}}}=6,463
$$

Frequency concordance testing was used to test this research question, where $\mathrm{U}=6.46$. Based on the test results, we can state that the proportion of private school students who see a strong point in interesting lectures and teaching methods is higher than that of Mendel university students.

$\mathbf{H}_{\mathrm{C}}$ : A contingency table test was used for testing. The assumption of the values of theoretical frequencies was fulfilled and we obtained a p-value of 0.001 using the goodness-of-fit test. We can therefore state that the strengths identified by male and female students are statistically significant. If we look at the differences in percentages, the biggest difference is in the strengths of quality teachers (mentioned by more male students) and involvement in the Erasmus program (mentioned by more female students).

$\mathbf{H}_{\mathrm{D}}$ : A contingency table test was used to verify this research question. Thanks to the goodness-of-fit test, it was proved that the strengths of students at the private school and FBE MENDELU differ significantly. A more detailed analysis of the data shows that students at the private university more often have interesting lectures and subjects, enough study materials, a pleasant atmosphere, and enough exam dates (all these indicators can be summarized in the field of student care). This type of strength was not identified with FBE MENDELU students. On the contrary, FBE MENDELU students present within the strengths of FBE MENDELU image, international cooperation, attractive fields, modern technologies, a pleasant atmosphere, and campus facilities. We could summarize these indicators in amenities and connections with the environment. Figure 5 documents the most frequently mentioned strengths of both types of universities.

\begin{tabular}{|c|c|}
\hline FBE MENDELU & Private university \\
Quality pedagogical staff (196) & Quality pedagogical staff (121) \\
Image of faculty (110) & Interesting lectures and teaching (104) \\
Modern environment (108) & Study materials for subjects (75) \\
Campus facilities (71) & Offer of interesting subjects (64) \\
Erasmus travel opportunities (60) & Pleasant atmosphere (46) \\
Faculty location (58) & Attractive fields (38) \\
University's tradition (48) & University location (38) \\
\hline
\end{tabular}

Figure 5

Strengths by type of university 
The obtained results can be compared with the survey, which was carried out in 2016. This survey was part of the pan-European survey EUROSTUDENT VI and in the Czech Republic 22,207 students participated with 16,653 completed questionnaires. Students in private schools are more satisfied than those in public schools with the quality of teaching (79.2\% and $73.8 \%)$ and the approach of teachers $(85.9 \%$ and $71.5 \%) .{ }^{54}$ According to the results of a questionnaire survey conducted at a selected university, respondents focus on evaluating strengths primarily on student care (quality of teachers, interesting lectures, offer of interesting subjects (see Fig.1). In public universities the strengths of the modern environment and background were identified, as well as in the study of the pan-European EUROSTUDENT survey.

According to that, students were satisfied with the equipment of the school (77.8\% in public universities and $69.3 \%$ in private ones) and with a wide range of subjects (52\% in public universities and $48 \%$ in private ones). ${ }^{55}$ Graduate surveys represent an important part of the range of information used to assess the quality of higher education. A quarter of the graduates stated that $80 \%$ of them met with very high-quality teachers. A total of 37 universities - 23 public and 14 private - took part in the survey, and the total set consisted of 21,166 completed questionnaires. The target group was university graduates from 2013-2017 (1 to 5 years after obtaining a diploma). ${ }^{56}$ The results of the questionnaire survey conducted by the authors also coincide in their conclusions with this survey, where students of the private and public university evaluate quality teaching staff as a strength (FBE MENDELU 57.6\%, private university 50.4\%).

\section{Implications and conclusion}

The aim of the paper was to verify what factors are important regarding students' satisfaction and could be key for supporting the competitiveness of

${ }^{54}$ Jakub Fišer et al., Basic Results of a Survey of Attitudes and Living Conditions of University Students in the Czech Republic. [Základní výsledky šetření postojů a životních podmínek studentů vysokých škol v České republice] (Ministry of Education, Youth and Sports (MEYS), 2016), https://www.msmt.cz/uploads/odbor_30/TF/Analyticke_materialy/ Eurostudent/E_VI_zaverecna_zprava.pdf.

55 Jakub Fišer et al., Basic Results of a Survey of Attitudes and Living Conditions of University Students in the Czech Republic, [Základní výsledky šetření postojů a životních podmínek studentů vysokých škol v České republice] (Ministry of Education, Youth and Sports (MEYS), 2016), https://www.msmt.cz/uploads/odbor_30/TF/Analyticke_materialy/ Eurostudent/E_VI_zaverecna_zprava.pdf.

${ }^{56}$ Martin Zelenka et al., Summary Report of the Graduate, of the Survey 2018 [Souhrnná zpráva o šetření absolvent 2018] (Center for Educational Policy, Faculty of Education, Charles University and Center for Higher Education Studies, v.v.i., 2019), https://www.msmt.cz/ file/51597_1_1/. 
Czech universities and colleges. Within the implemented questionnaire survey among students of FBE MENDELU and the private university, it was ascertained that each of the groups of students emphasized other factors in the evaluation of strengths. Among the strengths of private university students there are factors from the field of student care: interesting lectures and subjects, plenty of study materials, a pleasant atmosphere, and enough exam dates. On the other hand, FBE MENDELU'S strengths are mainly factors in school facilities and connections with the environment, such as the image of the faculty, international cooperation, attractive fields, modern technologies, a pleasant atmosphere, and campus facilities. At both universities, students were positively evaluated by teachers. They have also shown their qualities with a smooth transition to online teaching. They would certainly appreciate it if their efforts were rewarded, for example, by the Dean's award. At present, they are rewarded for scientific research rather than teaching.

In the area of weaknesses, and thus having further room for improvement and increasing competitiveness, according to the results of a questionnaire survey at FBE MENDELU, the most common weaknesses were identified as study difficulty (42.4\%), the weaker image of the university (as it used to be referred to in the past by the public as "Manure College") (31.5\%) and lack of practical training (23.2\%). Regarding the weakness of the "difficulty of studying" at FBE MENDELU, in the opinion of the authors, this factor is influenced by the level of previous education of students (grammar school students complain about economics and students of economics-oriented schools about mathematics) and the fact that more and more of them have specific educational needs. Given that the interviewing took place with second and third grade students, the probability that these students will not complete their bachelor's studies is no longer very high. Even though the "weaker image of the university with the public" appeared as a weak point, the students, on the contrary, considered the image of the faculty as a strength. The most significant factor, which FBE MENDELU should improve, is combining teaching with practical training. Although the faculty uses expert practitioners in lectures and students have a mandatory internship in bachelor's and master's studies, this factor is still perceived as a weakness. In the case of the private university, the weak points are perceived mainly as the lengthy processing through the study department (27.5\%), the large number of seminar papers (25.5\%), and the insufficient capacity of the school premises $(24.3 \%)$. The seminar work provides students with an opportunity to solve practical tasks and questions that suitably complement the theoretical knowledge. Nowadays, online 
classes are also an opportunity to better verify students' knowledge. Deepening the identified strengths and the simultaneous elimination of weaknesses should enable both universities to increase their competitiveness. Student satisfaction is then reflected in positive references that improve school evaluation in national comparisons, and the authors believe that in the future, student evaluation will be reflected in international university evaluations too.

\section{Bibliography}

Amoli, Sara Javan, and Farnouche Aghashahib. "An Investigation on Strategic Management Success Factors in an Educational Complex." Procedia - Social and Behavioral Sciences 230 (September 12, 2016): 447-54. https://doi.org/10.1016/j. sbspro.2016.09.056.

Anowar, Farzana, Mustakim A. Helal, Saida Afroj, Sumaiya Sultana, Farhana Sarker, and Khondaker A. Mamun. "A Critical Review on World University Ranking in Terms of Top Four Ranking Systems." Lecture Notes in Electrical Engineering, 2014, 559-66. https://doi.org/10.1007/978-3-319-06764-3_72.

Avralev, Nikita, and Irina Efimova. "University Rankings as a Tool for Assessing the Quality of Education in the Context of Globalization." Asian Social Science 11, no. 10 (2015): 292. https://doi.org/10.5539/ass.v11n10p292.

Barnard, Zenia, and Derek Van der Merwe. "Innovative Management for Organizational Sustainability in Higher Education." International Journal of Sustainability in Higher Education 17, no. 2 (March 7, 2016): 208-27. https:// doi.org/10.1108/ijshe-08-2014-0120.

Bowman, Nicholas A., and Michael N. Bastedo. "Getting on the Front Page: Organizational Reputation, Status Signals, and the Impact of U.S. News and World Report on Student Decisions." Research in Higher Education 50 (February 24, 2009): 415-36. https://doi.org/10.1007/s11162-009-9129-8.

Clark, Delwyn N. "Strategic Management Tool Usage: a Comparative Study." Strategic Change 6, no. 7 (November 1997): 417-427. https://doi.org/10.1002/ (SICI)1099-1697(199711)6:7 <417: AID-JSC281>3.0.CO;2-9.

Correia Loureiro, Sandra Maria, and Francisco Javier Miranda Gonzalez. "DUAQUAL: The Quality Perceived by Teachers and Students in University Management." Cuadernos de Gestión 12, no. 1 (2012): 107-22. https://doi. org/10.5295/cdg.100251sc.

Dearden, James A., Rajdeep Grewal, and Garry L. Lilien. "Strategic Manipulation of University Rankings, the Prestige Effect, and Student University Choice." Journal of Marketing Research 56, no. 4 (May 30, 2019): 691-707. https://doi. org/10.1177/0022243719831258.

Dimitrova, G., and T. Dimitrova. "Competitiveness of the Universities: Measurement Capabilities." Trakia Journal of Science 15, no. Suppl.1 (2017): 311-16. https:// doi.org/10.15547/tjs.2017.s.01.055. 
Education - Analysis, Comments. [Vzdělávání - Analýzy, komentáře]. Czech statistical Office, August 28, 2019. https://www.czso.cz/csu/czso/vzdelavanianalyzy-komentare.

Ehrenberg, Ronald G. "Reaching for the Brass Ring: The US News \& World Report Rankings and Competition." The Review of Higher Education 26, no. 2 (2003): 145-162. https://doi.org/10.1353/rhe.2002.0032.

Federkeil, Gero. "Rankings and Quality Assurance in Higher Education." Higher Education in Europe 33, no. 2-3 (2008): 219-31. https://doi.org/10.1080/ 03797720802254023.

Fišer, Jakub, Martina Šimková, Veronika Ptáčková, Petr Mazouch, Hana Lipovská, Michaela Brázdilová, and Kristýna Vltavská. Basic Results of a Survey of Attitudes and Living Conditions of University Students in the Czech Republic. [Základní výsledky šetření postojů a životních podmínek studentů vysokých škol v České republice] Ministry of Education, Youth and Sports (MEYS), 2016. https://www.msmt.cz/uploads/odbor_30/TF/Analyticke_materialy/Eurostudent/ E_VI_zaverecna_zprava.pdf.

Gan, Connie, Abdul Rahman, Parameswaran Subramanian, Rahiza Ranom, and Zahir Osman. "Exploring Key Factors Influencing University Choice: An Empirical Study on Malaysia Students.” 1st International Digital Conference on Modern Business and Social Science, December 13, 2018. https://doi. org/10.13140/RG.2.2.16662.80962.

Hazelkorn, Ellen. Rankings and the Reshaping of Higher Education: the Battle for World-Class Excellence. Basingstoke: Palgrave Macmillan, 2015.

Hazelkorn, Ellen. "Rankings and Higher Education: Reframing Relationships within and between States." Center for global higher education, May 2017. https:// www .researchcghe.org/publications/working-paper/rankings-and-highereducation-reframing-relationships-within-and-between-states/.

Hazelkorn, Ellen. "The Dubious Practice of University Rankings." Elephant in the Lab. Elephant in the Lab, April 23, 2019. https://elephantinthelab.org/theaccuracy-of-university-rankings-in-a-international-perspective/.

Hindls, Richard, Stanislava Hronová, Jan Seger, and Jakub Fischer. Statistics for Economists. [Statistika pro ekonomy] Průhonice, Czech Republic: Professional publishing, 2007.

Hutyra, Milan. The Way from Quality Management System to Excellence at the University Environment. February 15, 2008. https://ep.liu.se/en/conferencearticle.aspx ?series=ecp\&issue $=26 \&$ Article_No=126.

Chen, Yining, and Leon B. Hoshower. "Student Evaluation of Teaching Effectiveness: An Assessment of Student Perception and Motivation." Assessment \& evaluation in higher education 28, no. 1 (2003): 71-78. https://doi.org/10.1080/02602930301683.

Chui, Teo Boon, Mohd Shukur bin Ahmad, Faezah binti Ahmad Bassim, and Nurnadirah binti Ahmad Zaimi. "Evaluation of Service Quality of Private Higher Education Using Service Improvement Matrix." Procedia-Social and Behavioral Sciences 224 (June 15, 2016): 132-40. https://doi.org/10.1016/j. sbspro.2016.05.417. 
Indicators of the Strategy of Educational Policy of the Czech Republic until 2020. [Indikátory strategie vzdělávací politiky České republiky do roku 2020] Ministry of Education, Youth and Sports (MEYS) online. January 12, 2014. https://www. msmt.cz/file/34419/.

Jalote, Pankaj. "India's Quest for World-Ranked Universities." Current Science 16, no. 9 (May 2019): 1479-82. https://doi.org/10.18520/cs/v116/i9/1479-1482.

Khairunnisa, Khairunnisa, and Nila Krisnawati. "The Emergence of Service Quality and Brand Awareness toward Strategic Competitiveness and Its Impact on Hotel Performance." Journal of Business on Hospitality and Tourism 1, no. 1 (2015): 16. https://doi.org/10.22334/jbhost.v1i1.22.

Karadağ, Engin, and Cemil Yücel.(PDF) Türkiye Üniversite Memnuniyet Araştırması [Tüma-2016]. Accessed October 6, 2021. https://www.researchgate.net/ publication/305207486_Turkiye_Universite_Memnuniyet_Arastirmasi_ TUMA-2016.

Kaycheng, Soh. "What the Overall Doesn't Tell about World University Rankings: Examples from ARWU, QSWUR, and THEWUR in 2013." Journal of Higher Education Policy and Management 37, no. 3 (May 5, 2015): 295-307. https:// doi.org/10.1080/1360080X.2015.1035523.

Kurbatov, Sergiy. "University Rankings and the Problem of Competitiveness of National Universities of Post-Soviet Countries in Global Educational Space: the Case of Ukraine." Evaluation in Higher Education 6, no. 2 (December 1, 2012): 59-75. https://doi.org/ 10.6197/EHE.2012.0602.04.

Kusumastuti, Dyah, and Nirwan Idrus. "Nurturing Quality of Higher Education through National Ranking: a Potential Empowerment Model for Developing Countries." Quality in Higher Education 23, no. 3 (2017): 230-48. https://doi.or g/10.1080/13538322.2017.1407400.

Luca, Michael, and Jonathan Smith. "Strategic Disclosure: The Case of Business School Rankings." Journal of Economic Behavior \& Organization 12 (April 2015): 17-25. https://doi.org/10.1016/j.jebo.2014.12.023.

Marginson, Simon. "Global University Rankings: Implications in General and for Australia." Journal of Higher Education Policy and Management 29, no. 2 (April 8, 2008): 131-42. https://doi.org/10.1080/13600800701351660.

Marsh, Herbert W., and Lawrence A. Roche. "Effects of Grading Leniency and Low Workload on Students ' Evaluations of Teaching: Popular Myth, Bias, Validity, or Innocent Bystanders?” Journal of Educational Psychology 92, no. 1 (2020): 202-28. https://doi.org/10.1037/0022-0663.92.1.202.

Mendelu among the Best Schools in the World. [Mendelu mezi nejlepšími školami světa] Mendel University in Brno. Accessed June 23, 2020. http://mendelu. cz/32873n-mendelu-mezi-nejlepsimi-skolami-sveta.

Moosa, Raazia. "World University Rankings: Reflections on Teaching and Learning as the Cinderella Function in the South African Higher Education System." African Journal of Business Ethics 12, no. 1 (June 26, 2018): 38-59. https://doi. org/10.15249/12-1-165. 
Multirank: Universities Compared. Your Way. U. Accessed October 23, 2020. https://www.umultirank.org/compare?trackType=compare \&sightMode=undefi ned $§ i o n=$ compareSubject $\&$ mode=likewithlike $\&$ instutionalField=true $\&$ pref4=3\&country=42\&count \&name=null.

Olcay, Gokcen Arkali, and Melih Bulu. "Is Measuring the Knowledge Creation of Universities Possible? A Review of University Rankings." Technological Forecasting and Social Change 123 (October 2017): 153-60. https://doi. org/10.1016/j.techfore.2016.03.029.

O`Malley, Brendan. Global University Rankings Data Are Flawed` - HEPI. Univerzity World News, December 15, 2016. https://www.universityworldnews. com/post.php?story=20161215001420225.

Ondrušová, Adriana. Students and Graduates of Universities and Colleges in the Czech Republic. [Studenti a absolventi vysokých a vyšších odborných škol v České republice] Czech statistical Office, 2020. https://www.czso.cz/csu/czso/ studenti-a-absolventi-vysokych-a-vyssich-odbornych-skol-v-cr-2018.

Overview of Universities in the Czech Republic. [Přehled vysokých škol v ČR] Ministry of Education, Youth and Sports (MEYS). Accessed July 20, 2020. https:// www.msmt.cz/vzdelavani/vysoke-skolstvi/prehled-vysokych-skol-v-cr-3.

Palli, Janardhana Gundla, and Rajasekhar Mamilla. "Students' Opinions of Service Quality in the Field of Higher Education." Creative Education 3, no. 4 (August 10, 2012): 430-38. https://doi.org/10.4236/ce.2012.34067.

QS World University Ranking 2021. Top Universities. Accessed June 30, 2020. https://www.topuniversities.com/universities/country/czech-republic.

Readings, Bill. The University in Ruins. Cambridge, Mass: Harvard University Press, 1999.

Richardson, John T.E. "Instruments for Obtaining Student Feedback: A Review of the Literature." Assessment \& Evaluation in Higher Education 30, no. 4 (September 14, 2010): 387-415. https://doi.org/10.1080/02602930500099193.

Rusite, Evija, and Biruta Sloka. "Importance of Collaboration with Employers towards the Rankings of Higher Education Institutions." 20th International Scientific Conference „Economic Science for Rural Development 2019“. New Dimensions in the Development of Society. Home Economics. Finance and Taxes. Bioeconomy., May 8, 2019. https://doi.org/10.22616/esrd.2019.113.

Ruiz de Sabando, Amaia Lafuente, Javier Forcada, and Pilar Zorrilla. "The University Image: a Model of Overall Image and Stakeholder Perspectives." Management Letters Cuadernos de Gestión 19, no. 1 (2019): 63-86. https://doi.org/10.5295/ cdg.160720al.

Sayed, Osama H. "Critical Treatise on University Ranking Systems." Open Journal of Social Sciences 07, no. 12 (2019): 39-51. https://doi.org/10.4236/ jss.2019.712004.

Shin, Jung Cheol, Robert Kevin Toutkoushian, and Ulrich Teichler. University Rankings: Theoretical Basis, Methodology and Impacts on Global Higher Education. Dordrecht: Springer, 2013. 
Šmejkalová, Julie. "The Process of Evaluating Strategic Trends in the Provision of Quality Higher Education-Analysis of the External Environment." Economic Letters. College of Economics and Management, December 28, 2016. http:// search.ebscohost.com/login.aspx?direct=true $\& \mathrm{db}=\mathrm{bsu} \& \mathrm{an}=120576379 \&$ scope $=$ site.

Štefánková, Jana, and Oliver Moravčík. "An Approach to the Quality Assessment of Higher Education Institutions via Knowledge Management Principles.” DSpace Home page. Academic Publishing International (API), January 1, 2012. https:// publikace.k.utb.cz/handle/10563/1003104.

Transition of High School Graduates to Tertiary Education - 2017/18. [Přechod absolventů středních škol do terciálního vzdělávání - 2017/18] National institute for education. Accessed June 22, 2020. https://www.infoabsolvent.cz/Temata/ PublikaceAbsolventi?Stranka=9-0-152.

World University Rankings. Times Higher Education (THE) online. February 11, 2020. https://www.timeshighereducation.com/world-university-rankings/2020/ world-ranking\#!/page/0/length/25/sort_by/rank/sort_order/asc/cols/stats.

Zelenka, Martin, Jan Sedláček, Michaela Šmídová, Vítězslav Lounek, Radim Ryška, and Jan Koucký. Summary Report of the Graduate, of the Survey 2018. [Souhrnná zpráva o šetření absolvent 2018] Center for Educational Policy, Faculty of Education, Charles University and Center for Higher Education Studies, v.v.i., 2019. https://www.msmt.cz/file/51597_1_1/.

Zeithaml, Valarie A., Mary Jo Bitner, and Dwayne D. Gremler. "Services Marketing: Integrating Customer Focus Across the Firm - 7th Ed.” [Vui lòng dùng định danh này để trích dẫn hoặc liên kết đến tài liệu này] Thư viện số Văn Lang: Trang chủ. McGraw-Hill Education, January 1, 1970. http://thuvienso. vanlanguni.edu.vn/handle/Vanlang_TV/19151.

\section{About the authors}

HELENA CHLÁDKOVÁ (corresponding author, chlad@mendelu.cz) is an associate professor at Mendel University in Brno in the Czech Republic. She received her habitation in 2013 at the Faculty of Business and Economics of Mendel University in Brno in the field of Economics and Management with the title of habilitation thesis: The role of the environment in the development of small and medium-sized enterprises. She is the Deputy Head of the Management Department. Her research interests include quality management, performance management, strategic management, SME competitiveness and human resource development. She publishes mainly in the field of business competitiveness and business performance. She is also interested in the processing industry and viticulture and winemaking. She currently teaches general management, business management and integrated management at four faculties of Mendel University in Brno. He also has experience in conducting bachelor's, master's and rigorous theses. Under her leadership, 76 bachelor's theses, 44 diploma theses and 5 dissertations were successfully defended. 
RENATA SKÝPALOVÁ (renata.skypalova@ambis.cz), PhD in Economics and Management, is an assistant professor at Ambis College, a.s. in Brno in the Czech Republic. She achieved her doctoral degree in 2014 at the Faculty of Business and Economics of Mendel University in Brno in the field of Economics and Management with the title of the dissertation thesis: Corporate Social Responsibility concept. Her research interests include human resource management, employer branding, small and medium enterprises competitiveness, and human resource development. She publishes mainly in the field of corporate social responsibility, and human resources management. She currently teaches human resources management, leadership, education and development management, and methods of personal works at Ambis College, a. s. in Brno. She also has experience in conducting bachelor's and master's theses. Under her leadership, 35 bachelor's theses, 15 diploma theses have been successfully defended.

VERONIKA BLAŠKOVÁ (veronika.blaskova@mendelu.cz) is an associate professor at Mendel University in Brno in the Czech Republic. She received her habilitation in 2021 at the Faculty of Business and Economics of Mendel University in Brno in the field of Economics and Management. She is a member of the following bodies at MENDELU: Academic Senate (Faculty of Business and Economics), Dean's panel for quality of education (Faculty of Business and Economics, Rector's Committee for Timetable Completion and Dean's Committee for Course Timetables (Faculty of Business and Economics). She currently teaches statistics, applied statistics, operational research, econometrics, and methodology of food research. Under her leadership, 78 bachelor's theses and 50 diploma theses were successfully defended. She publishes mainly in the field of business competitiveness and business performance and in the field of sector analysis. She focuses on applied mathematics and statistics. She regularly participates in international conferences. 



\title{
Strengthening the university competitiveness in the Czech Republic
}

\author{
Helena Chládková, Renata Skýpalová, and Veronika Blašková
}

doi: http://dx.doi.org/10.18543/tjhe-9(1)-2021pp127-155

\section{Copyright}

Copyright for this article is retained by the Publisher. It is an Open Access material that is free for full online access, download, storage, distribution, and or reuse in any medium only for noncommercial purposes and in compliance with any applicable copyright legislation, without prior permission from the Publisher or the author(s). In any case, proper acknowledgement of the original publication source must be made and any changes to the original work must be indicated clearly and in a manner that does not suggest the author's and or Publisher's endorsement whatsoever. Any other use of its content in any medium or format, now known or developed in the future, requires prior written permission of the copyright holder. 